\begin{abstract}
Iranica
Abstracta Iranica Revue bibliographique pour le domaine irano-aryen

Volume 34-35-36 | 2017

Comptes rendus des publications de 2011-2013
\end{abstract}

\title{
Harold W. Attridge, Julian V. Hills (ed.). The Acts of Thomas
}

Christelle Jullien

\section{(2) OpenEdition \\ 12 Journals}

\section{Édition électronique}

URL : http://journals.openedition.org/abstractairanica/41297

DOI : 10.4000/abstractairanica.41297

ISSN : 1961-960X

Éditeur :

CNRS (UMR 7528 Mondes iraniens et indiens), Éditions de l'IFRI

Référence électronique

Christelle Jullien, « Harold W. Attridge, Julian V. Hills (ed.). The Acts of Thomas », Abstracta Iranica [En ligne], Volume 34-35-36 | 2017, document 6, mis en ligne le 15 juillet 2016, consulté le 03 octobre 2020. URL : http://journals.openedition.org/abstractairanica/41297 ; DOI : https://doi.org/10.4000/ abstractairanica.41297

Ce document a été généré automatiquement le 3 octobre 2020.

Tous droits réservés 


\title{
Harold W. Attridge, Julian V. Hills (ed.). The Acts of Thomas
}

\author{
Christelle Jullien
}

\section{RÉFÉRENCE}

Harold W. Attridge, Julian V. Hills (ed.). The Acts of Thomas. Salem (USA), Polebridge Press, 2010, $157 \mathrm{p}$.

1 Cette nouvelle version des Actes grecs de l'apôtre Thomas augmentée d'une introduction littéraire et historique présente l'intérêt d'une mise en perspective des différences entre les versions grecques et syriaques. L'A. réévalue la tradition manuscrite et livre un index des parallèles thématiques et des citations d'écrits canoniques et extra-canoniques, en incluant la littérature apocryphe et les écrits coptes de la Bibliothèque de Nag Hammadi. Il pose l'hypothèse d'une influence de la tradition bartholoméenne sur la rédaction des Actes, spécialement pour le voyage de Thomas vers l'Inde : la mission de Judas Thomas chez le roi Gundafarr serait une réappropriation par les chrétiens d'Osrhoène de la mission de Barthélemy dans les territoires de la mer Érythrée (allusion en particulier chez Pantène). Il se situe dans la lignée des réflexions d'Albrecht Dihle qui, dans un article paru en 1963, considérait que la tradition relative à Barthélemy était antérieure à celle faisant de Thomas le premier apôtre de l'Inde (« Neues zur Thomastradition ». Jahrbuch für Antike und Christentum 6, Münster, 1963, p. 54-70, ici p. 68-69). 


\section{AUTEURS}

\section{CHRISTELLE JULLIEN}

CNRS, Mondes iranien et indien, Paris 